\title{
Molecular Characterization of a Novel Species of Capillovirus from Japanese Apricot (Prunus mume)
}

\author{
Armelle Marais * (iD, Chantal Faure, Sébastien Theil and Thierry Candresse \\ UMR 1332 Biologie du Fruit et Pathologie, INRA, University Bordeaux, CS 20032, 33882 Villenave d'Ornon, \\ France; chantal.faure@inra.fr (C.F.); sebastien.theil@inra.fr (S.T.); thierry.candresse@inra.fr (T.C.) \\ * Correspondence: armelle.marais-colombel@inra.fr; Tel.: +33-557-122-379
}

Received: 8 February 2018; Accepted: 21 March 2018; Published: 23 March 2018

\begin{abstract}
With the increased use of high-throughput sequencing methods, new viruses infecting Prunus spp. are being discovered and characterized, especially in the family Betaflexiviridae. Double-stranded RNAs from symptomatic leaves of a Japanese apricot (Prunus mume) tree from Japan were purified and analyzed by Illumina sequencing. Blast comparisons of reconstructed contigs showed that the P. mume sample was infected by a putative novel virus with homologies to Cherry virus $A$ (CVA) and to the newly described Currant virus A (CuVA), both members of genus Capillovirus. Completion of the genome showed the new agent to have a genomic organization typical of capilloviruses, with two overlapping open reading frames encoding a large replication-associated protein fused to the coat protein (CP), and a putative movement protein (MP). This virus shares only, respectively, $63.2 \%$ and $62.7 \% \mathrm{CP}$ amino acid identity with the most closely related viruses, $\mathrm{CVA}$ and $\mathrm{CuVA}$. Considering the species demarcation criteria in the family and phylogenetic analyses, this virus should be considered as representing a new viral species in the genus Capillovirus, for which the name of Mume virus A is proposed.
\end{abstract}

Keywords: Next Generation Sequencing; fruit tree viruses; Betaflexiviridae; Mume virus A; Capillovirus

\section{Introduction}

Since the advent of high-throughput sequencing methods in the plant virology field, a number of new viruses infecting Prunus spp. have been described [1,2]. In particular, a significant number of new viruses belonging to the Betaflexiviridae family have been discovered and characterized, leading to the introduction of two novel genera, Prunevirus [3] and Robigovirus [4]. More recently, a novel viral species belonging to the family Secoviridae has been described in peach, for which the name of Peach leaf pitting-associated virus was proposed [5]. Two marafiviruses in the Tymoviridae family were also recently reported from nectarine and peach: the nectarine virus $M$ and the peach virus $D$, respectively [6,7].

Prunus mume, also known as Japanese apricot, belongs to the genus Prunus in the family Rosaceae and originates from China. It has been cultivated throughout East Asia for fruit production, as well as for ornamental purposes. Besides its cultural significance, $P$. mume is also cultivated for culinary or medicinal uses. To this date, 15 viroids or viral species from families Pospiviroidae, Closteroviridae, Bromoviridae, Potyviridae, Luteoviridae, Geminiviridae, and Betaflexiviridae have been described from symptomatic or from symptomless P. mume [2,8-11]. However, due to mixed infections, it is often difficult to associate the presence of a particular virus with the observed symptomatology. As for Prunus spp. in general, many of the viral species infecting P. mume belong to the Betaflexiviridae family. Four genera are thus represented in P. mume among the 11 comprised in the family, with eight viruses: Apricot latent virus (ApLV) and Asian prunus virus 1 and 2 (APV1, APV2) (Genus Foveavirus), Peach mosaic virus (PcMV) and Apple chlorotic leaf spot virus (ACLSV) (Genus Trichovirus), Apricot vein clearing 
associated virus (AVCaV) (Genus Prunevirus), and Apple stem grooving virus (ASGV) and Cherry virus A (CVA) (Genus Capillovirus) [2,12,13].

In the present study, the complete genome sequence of a novel viral species from a Japanese P. mume tree showing slight symptoms of diffuse chlorotic spots was determined by a high-throughput sequencing approach. Phylogenetic analyses allow one to conclude that this virus, for which the name of Mume virus A is proposed, belongs to the genus Capillovirus in the family Betaflexiviridae, extending our knowledge of Prunus-infecting viruses.

\section{Materials and Methods}

\subsection{Plant Materials, Viral Source, and Maintenance}

Symptomatic leaves from a Japanese apricot tree (P. mume, "PM14") showing diffuse chlorotic spots on leaves were collected in Japan (Kyoto province) and submitted to high-throughput sequencing analysis. The PM14 isolate was propagated by chip budding on GF305 peach seedlings under level 3 containment greenhouse conditions. Various Prunus sources from China, Japan, Czech Republic, Azerbaijan, Kazakhstan, Italy, and France, (P. mume, Prunus cerasus, Prunus avium, Prunus armeniaca, Prunus persica, Prunus sibirica, Prunus serrulata, Prunus salicina, Prunus domestica, Prunus dulcis, and Prunus holosericea) were screened by Reverse Transcription-Polymerase Chain Reaction (RT-PCR) for the presence of Mume virus A.

\subsection{Determination of the Herbaceous Host Range of PM14 Isolate}

Young leaves of GF305 infected with the PM14 source were used as the inoculum. Leaves were ground $(1 / 4$, weight $(w t) / v)$ in $50 \mathrm{mM}$ potassium phosphate buffer, $\mathrm{pH}$ 7.6. Before transmission, activated charcoal $(90 \mathrm{mg} / \mathrm{mL})$, nicotine hemisulfate $(2 \% v / v)$, and polyvinylpyrrolidone 40 (PVP40, 2\% v/v) were added to the homogenate. Carborundum (400 mesh) was used as the abrasive. The following plants were evaluated as potential hosts: Chenopodium amaranticolor, C. quinoa, Nicotiana benthamiana, Nicotiana tabacum cv. Xanthi, Nicotiana glutinosa, and Phaseolus vulgaris cv. Vedette. The appearance of symptoms was monitored over a three-week period.

\subsection{Analysis of Double-Stranded RNAs by High-Throughtut Sequencing and Completion of the PM14 Isolate} Genome Sequence

Double-stranded RNAs (dsRNAs) were extracted from symptomatic leaves of PM14 according to the protocol of Gentit et al. [14] with the modifications introduced by Candresse et al. [15]. The purified dsRNAs were then reverse-transcribed, randomly amplified, and submitted to Illumina sequencing in a multiplexing scheme as described by Candresse et al. [15]. After demultiplexing and quality trimming steps, the reads were assembled using CLC Genomics Workbench 6.5 (http:/ / www.clcbio. com) or a pipeline integrating the Newbler assembler. Contigs were then annotated by BlastN and BlastX comparison with the Genbank database (cut-off $e$-value $=10^{-3}$ ). Mapping on reference genomes allowed the ordering of the contigs and the reconstruction of a unique scaffold spanning the viral genome.

To complete the viral genome sequence, primers were designed from the contig sequences and used to amplify PCR products spanning the gaps between contigs (Table 1). The two genome ends were determined by a Rapid Amplification of Complementary DNA (cDNA)Ends strategy for the 5' end (SMARTER RACE $5^{\prime}$ kit, Takara Bio Europe/Clontech, Saint-Germain-en-Laye, France) and a RT-PCR using the LD-prime and an internal primer for the $3^{\prime}$ end (Table 1) following the protocol described by Youssef et al. [16]. The amplified fragments were submitted to Sanger sequencing (GATC Biotech, Mulhouse, France). 
Table 1. Primers used in this study to complete the genome sequence of the PM14 isolate.

\begin{tabular}{|c|c|c|c|}
\hline Primer Name & Sequence $\left(5^{\prime}-3^{\prime}\right)$ & Genome Coordinates & Amplicon Size (nt) \\
\hline Capillo-mume-5Race2 ${ }^{\#}$ & CCTTGCATGGTTGTTGTTGAAGTCCTCCC & $251-223$ & 252 \\
\hline Capillo-mume-F1 & AACAACAACCATGCAAGGTTTGAG & $234-257$ & \multirow{2}{*}{503} \\
\hline Capillo-mume-R1 & GCTAGAACACACTTAGGCCGCAA & $736-714$ & \\
\hline Capillo-mume-F2 & GGAATGTTGATACATACAGACA & $1629-1650$ & \multirow{2}{*}{742} \\
\hline Capillo-mume-R2 & CGTCTGAGCCTAATCCATACAC & $2370-2349$ & \\
\hline Capillo-mume-F3 & TGGATTTATTGAACTTCTCATAC & $2831-2853$ & \multirow{2}{*}{406} \\
\hline Capillo-mume-R3 & CGTCACAATCACACCAAATCTG & $3236-3215$ & \\
\hline Capillo-mume-F6 & GATGTACGAGGATTCAGTGG & $4034-4053$ & \multirow{2}{*}{451} \\
\hline Capillo-mume-R6 & AATGAGGGAGTTAGAAACACC & $4484-4464$ & \\
\hline Capillo-mume-R7 & ACCAACTGTTATGACAGATTC & $5117-5097$ & 1084 \\
\hline LD-PolyT $^{\circledR}$ & CACTGGCGGCCGCTCGAGCATGTAC(T)25NN & & \\
\hline Capillo-mume-LD & GAGCACCATTGGAGGGTGTGT & \multirow[t]{2}{*}{$7462-7482$} & \multirow{2}{*}{183} \\
\hline LD-Prime & CACTGGCGGCCGCTCGAGCATGTAC & & \\
\hline
\end{tabular}

\# This reverse primer was used in conjunction with the universal primer provided by the $5^{\prime}$ RACE kit (Takara Bio Europe/Clontech, Saint-Germain-en-Laye, France); This reverse primer was used in conjunction with the Capillo-mume-F6 primer; ${ }^{\circledR}$ This primer was used for the complementary DNA synthesis prior amplification with the primer pair Capillo-mume-LD and LD-Prime.

The sequence reported in the present manuscript has been deposited in the GenBank database under accession number MG783575.

\subsection{Total Nucleic Acid Extraction and RT-PCR Detection of Mume Virus A}

Extraction of total nucleic acids (TNAs) was performed according to the protocol 2 described by Foissac et al. [17]. Five microliters of TNAs were submitted to a reverse transcription using a mixture of $2 \mu \mathrm{M} \mathrm{dN6}$ and $1 \mu \mathrm{M}$ dT18 as reverse primers and the RevertAid Reverse Transcriptase following the recommendations of the manufacturer (Thermo Fisher Scientific, Illkirch, France). The cDNA was then amplified using $1 \mu \mathrm{M}$ of Capillo-mume-F1 and Capillo-mume-R1 primers (Table 1 ) and DyNAzyme II DNA polymerase according to the provider's instructions (Finnzymes/Thermo Fisher Scientific). Forty cycles were applied, each of $95{ }^{\circ} \mathrm{C}$ for $30 \mathrm{~s}, 61^{\circ} \mathrm{C}$ for $30 \mathrm{~s}$, and $72{ }^{\circ} \mathrm{C}$ for $30 \mathrm{~s}$, followed by a final extension step of $10 \mathrm{~min}$ at $72{ }^{\circ} \mathrm{C}$.

\subsection{Phylogenetic Analyses}

Multiple alignments of nucleotide (nt) or amino acid (aa) sequences were performed using the ClustalW program [18] implemented in MEGA version 6.0 [19]. Genetic distances (p-distances using strict nt or aa identity) were calculated using MEGA 6.0. Phylogenetic reconstructions were performed using the neighbor-joining technique and randomized bootstrapping (1000 replicates) to evaluate the statistical significance of branches.

\section{Results and Discussion}

\subsection{Illumina Sequencing of Double-Stranded RNAs Purified from the PM14 Japanese Apricot Source}

Double-stranded RNAs purified from the PM14 source were sequenced on an Illumina Miseq platform using paired-end sequencing $(2 \times 250 \mathrm{nt})$. After demultiplexing, quality trimming, and de novo assembly of the 33,113 reads obtained for that sample, Blast analysis allowed one to identify ten contigs sharing significant identity with known plant viruses. Four contigs integrating $1.6 \%$ of total reads were tentatively identified as belonging to a luteovirus (under characterization). The six remaining viral contigs integrated $1.59 \%$ of the reads and showed between $71 \%$ and $78 \%$ nt identity ( $54 \%$ to $83 \%$ aa identity for the encoded proteins) with the corresponding regions of two members of the genus Capillovirus, CVA or Currant virus A (CuVA). These contigs, tentatively identified as belonging to a capillovirus, were manually assembled by mapping to CVA genome, in order to create a scaffold of $6542 \mathrm{nt}$ missing the $5^{\prime}$ and $3^{\prime}$ genome ends and containing five internal gaps. The genome sequence of 
the PM14 isolate was completed by targeted PCR as described in the Materials and Methods section. The assembled complete genome sequence was deposited in the GenBank database under accession number MG783575.

\subsection{Genome Organization and Phylogenetic Relationships of PM14 Isolate}

The genome of the PM14 isolate has a size of $7644 \mathrm{nt}$, excluding the polyA tail. It encodes two overlapping open reading frames (ORFs), with an overall genome organization similar to that of capilloviruses (Figure 1). A phylogenetic tree reconstructed using the complete genome sequences of representative members of the Betaflexiviridae family shows that the new virus clusters with other capilloviruses with a highly significant bootstrap value (99\% in Figure 2$)$ and, more specifically, that it forms a sub-cluster together with CVA and CuVA.

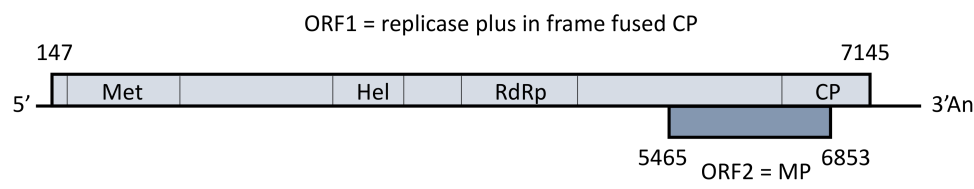

Figure 1. Schematic representation of the genome organization of PM14 isolate. The two predicted open reading frames (ORFs) are represented by boxes, with nucleotide coordinates indicated. Conserved motifs for viral methyltransferase (pfam 01660, Met), viral helicase_1 (pfam 01443, Hel), and RNA-dependent RNA polymerase_2 (pfam 00978, RdRp) domains are shown within ORF1, as well as the coat protein $(\mathrm{CP})$ domain. MP, movement protein. $5^{\prime}$ and $3^{\prime}$ non coding regions are shown by black lanes at both extremities. An: polyA tail.

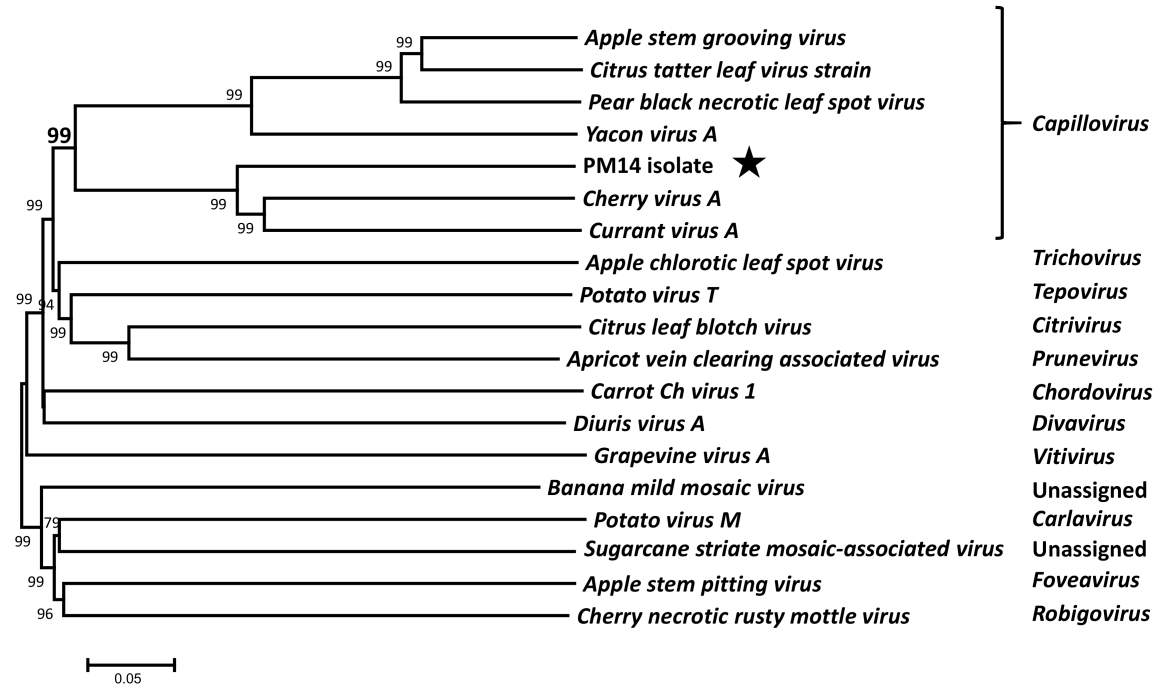

Figure 2. Unrooted phylogenetic tree reconstructed using the complete genome sequences of representative Betaflexiviridae members. The tree was constructed using the neighbor-joining method, and the statistical significance of branches was evaluated by bootstrap analysis (1000 replicates). Bootstrap values above $70 \%$ are shown. The scale bar represents $5 \%$ divergence between sequences. Sequences retrieved from GenBank are NC001749 Apple stem grooving virus; AY646511 Citrus tatter leaf virus; AY596172 Pear black necrotic leaf spot virus; NC030657 Yacon virus A; NC003689 Cherry virus A; NC029301 Currant virus A; NC001409 Apple chlorotic leaf spot virus; NC011062 Potato virus T; NC003877 Citrus leaf blotch virus; NC023295 Apricot vein clearing associated virus; NC025469 Carrot Ch virus 1; NC019029 Diuris virus A; NC003604 Grapevine virus A; NC002729 Banana mild mosaic virus; NC001361 Potato virus M; NC003870 Sugarcane striate mosaic-associated virus; and NC002468 Cherry necrotic rusty mottle virus. The genus to which each virus belongs is indicated at the right. The PM14 isolate is indicated by a black star. 
The ORF1 (2333 aa) encodes a large replication-associated protein (aa 1-2105) fused to the coat protein (CP, aa 2106-2333). Three conserved domains typical for Betaflexiviridae replicases are found within the ORF1 protein: a viral methyltransferase domain (pfam 01660, aa 43-351), a viral helicase 1 domain (pfam 01443, aa 812-1089), and a RNA-dependent RNA polymerase 2 domain (pfam 00978, aa 1213-1541). No AlkB domain (2OG-FeII-Oxy-2-domain) has been identified within the ORF1 protein, as for most of Capillovirus members, with the exception of CuVA ORF1 in which AlkB domain was found between aa 623 and 736 [20,21]. The second ORF encodes a putative movement protein (MP, $463 \mathrm{aa}$ ). The two non-coding regions (NCR) located at the $5^{\prime}$ and $3^{\prime}$ ends of the genome are 146 and $499 \mathrm{nt}$ long, respectively. Both NCRs are thus significantly longer than those of other capilloviruses, which are reported to be between 35 and 93 nt ( $5^{\prime}$ NCR of ASGV and CuVA, respectively) and between 122 and $303 \mathrm{nt}$ ( $3^{\prime}$ NCR of Yacon virus A and CVA, respectively). Interestingly, the size of the $5^{\prime}$ and $3^{\prime}$ NCRs seems to be correlated with the clustering of CVA, CuVA, and the PM14 isolate in the same phylogenetic group, and the same applies to the size of the various proteins (Table 2).

Phylogenetic analyses based on alignments of $\mathrm{CP}$ or MP sequences from Capillovirus members confirm a clear clustering of the PM14 isolate with CVA and CuVA, with highly significant bootstrap values $(100 \%)$ (Figure 3A,B). The same clustering is also obtained using replicase sequences (data not shown). To complete this analysis, sequence identities were calculated among Capillovirus members for the replicase, the CP and the MP (Table 2). The level of identity between these proteins is distant, with, at best, only $65.4 \%$ of aa identity between PM14 isolate and CuVA in the CP, and $54.4 \%$ with $\mathrm{CVA}$ in the replicase. Considering the accepted species demarcation molecular criteria for the family Betaflexiviridae, which are of $72 \%$ nt identity (or $80 \%$ aa identity) in the replicase and CP genes [21], the PM14 isolate should be considered as a novel species in the genus Capillovirus. We therefore propose the name of Mume virus A (MuVA) for this species.

(A)
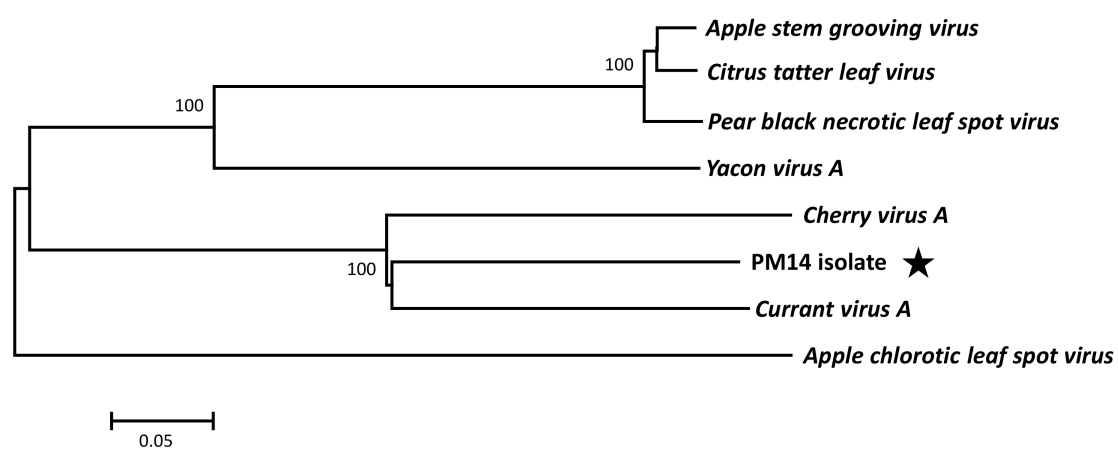

(B)

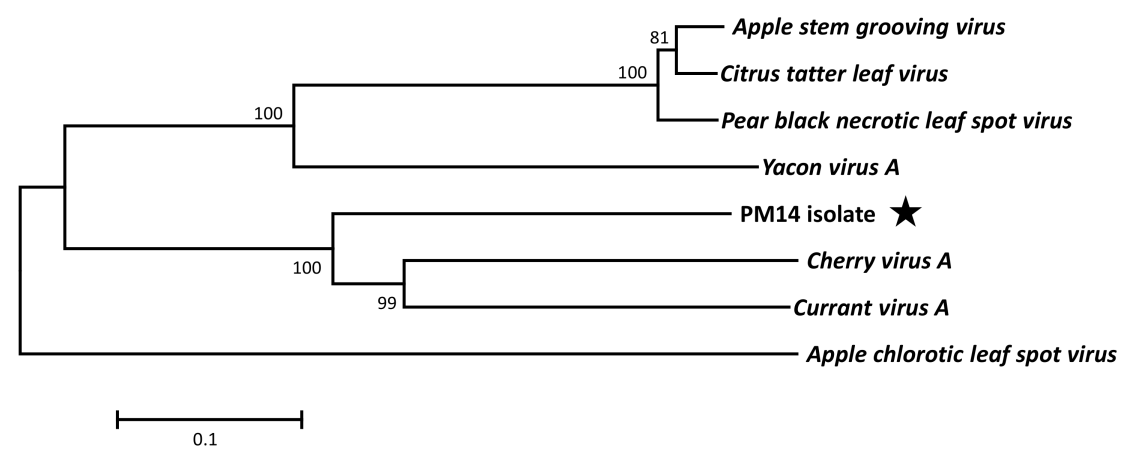

Figure 3. Neighbor joining phylogenetic trees reconstructed using the amino acid sequences of the coat protein (A) or movement protein (B) from Capillovirus members. Apple chlorotic leaf spot virus (NC001409 Trichovirus genus) was included as outgroup. The trees were constructed in Mega 6.0 using a strict amino acid identity distance. Bootstrap values above $70 \%$ (1000 replicates) are shown. The scale bars represent $5 \%(\mathbf{A})$ or $10 \%$ (B) divergence. Sequences retrieved from GenBank are the same as in Figure 2. The PM14 isolate is indicated by a black star. 
Table 2. Percentages of identity between the proteins encoded by the genome of the PM14 isolate and the corresponding proteins of Capillovirus members ${ }^{\#}$.

\begin{tabular}{cccc}
\hline \multirow{2}{*}{ Virus ${ }^{\circledR}$} & \multicolumn{3}{c}{ Percent Amino Acid Identity (Size [aa]) } \\
\cline { 2 - 4 } & Replicase (2105) & Coat Protein (228) & Movement Protein (463) \\
\hline CuVA & $53.7 \%(2296)$ & $\mathbf{6 5 . 4} \%(229)$ & $53.3 \%(462)$ \\
CVA & $\mathbf{5 4 . 4 \% ( 2 1 1 2 )}$ & $62.7 \%(232)$ & $53.7 \%(463)$ \\
ASGV & $25.7 \%(1868)$ & $32.1 \%(238)$ & $29.1 \%(321)$ \\
YVA & $24.6 \%(1868)$ & $30.2 \%(215)$ & $26.2 \%(324)$ \\
\hline
\end{tabular}

\# Sizes in amino acids (aa) of the proteins are indicated in parentheses. For each protein, the highest identity level is highlighted in bold. ${ }^{@}$ Acronyms used: CuVA $=$ Currant virus $A, \mathrm{CVA}=$ Cherry virus $A, \mathrm{ASGV}=$ Apple stem grooving virus, YVA = Yacon virus A.

\subsection{Biological Characterization and Incidence of Mume virus $A$}

Despite significant efforts to transmit MuVA to various herbaceous plants, none of the plant species tested could be successfully inoculated. No local or systemic symptoms appeared on inoculated plants, and RT-PCR assays performed to detect MuVA were all negative. MuVA was, however, successfully graft-transmitted to peach seedlings (GF305 indicator). However, no symptoms could be identified on leaves or in growth habit of the infected peach plants (data not shown). The initial tree in which MuVA was detected showed diffuse chlorotic spots on leaves. However, it is co-infected by a potentially novel luteovirus (currently under characterization), so that it is difficult to assess the role of MuVA in the symptomatology observed. Moreover, due to the dsRNA sequencing strategy used in the present study, the potential contribution in the observed symptoms of another agent such as a DNA virus or a viroid cannot be excluded. Among the capilloviruses described so far, four are known to infect fruit trees, which represent in fact only two viral distinct species, CVA and ASGV, since Citrus tatter leaf virus (CTLV) and Pear black necrotic leaf spot virus (PBNLSV) are recognized as citrus and pear isolates of ASGV, respectively [22,23]. CVA infection is very generally latent in its cherry hosts, and no symptoms are associated with ASGV infection on apple cultivars. Both viruses have been shown to be transmitted by grafting, but only ASGV was successfully transmitted to various herbaceous host species [24,25]. No natural vector is known so far for capilloviruses, and CVA and ASGV are not known to be epidemic and are apparently transmitted in the field only by grafting and by planting infected material [12,24]. To assess the incidence of MuVA, a total of 285 samples from various Prunus species originated from seven different countries were screened by a specific RT-PCR test (Capillo-mume-F1/R1; Table 1). No MuVA-infected sample was detected, even among P. mume samples collected in East Asian countries (China and Japan), suggesting a limited prevalence of MuVA. Further investigations are necessary to evaluate the distribution, prevalence, and potential pathogenicity of this new member of the Capillovirus genus.

Acknowledgments: The authors thank the Platform Genotoul (INRA, Toulouse, France) for the Illumina sequencing, and T. Mauduit and C. Chesseron for taking care of experimental plants.

Author Contributions: Conceived and designed the experiments: A.M., T.C. Performed the experiments: A.M., C.F. Analyzed the data: A.M., T.C. and S.T. Contributed reagents/materials/analysis tools: A.M., C.F., T.C. and S.T. Wrote the paper: A.M., T.C.

Conflicts of Interest: The authors declare no conflict of interest.

\section{References}

1. Roossinck, M.J.; Martin, D.P.; Roumagnac, P. Plant virus metagenomics: Advances in virus discovery. Phytopathology 2015, 105, 716-727. [CrossRef] [PubMed]

2. Rubio, M.; Martínez-Gómez, P.; Marais, A.; Sánchez-Navarro, J.A.; Pallás, V.; Candresse, T. Recent advances and prospects in Prunus virology. Ann. Appl. Biol. 2017, 171, 125-138. [CrossRef] 
3. Marais, A.; Faure, C.; Mustafayev, E.; Candresse, T. Characterization of new isolates of Apricot vein clearing-associated virus and of a new Prunus-infecting virus: Evidence for recombination as a driving force in Betaflexiviridae evolution. PLoS ONE 2015, 10, e129469. [CrossRef] [PubMed]

4. Villamor, D.E.; Susaimuthu, J.; Eastwell, K.C. Genomic analyses of Cherry rusty mottle group and Cherry twisted leaf-associated viruses reveal a possible new genus within the family Betaflexiviridae. Phytopathology 2015, 105, 399-408. [CrossRef] [PubMed]

5. He, Y.; Cai, L.; Zhou, L.; Yang, Z.; Hong, N.; Wang, G.; Li, S.; Xu, W. Deep sequencing reveals the first fabavirus infecting peach. Sci. Rep. 2017, 7, 11329. [CrossRef] [PubMed]

6. Villamor, D.E.; Mekuria, T.A.; Pillai, S.S.; Eastwell, K.C. High-throughput sequencing identifies novel viruses in nectarine: Insights to the etiology of stem-pitting disease. Phytopathology 2016, 106, 519-527. [CrossRef] [PubMed]

7. Igori, D.; Lim, S.; Baek, D.; Kim, S.Y.; Seo, E.; Cho, I.-S.; Choi, G.-S.; Lim, H.-S.; Moon, J.S. Complete nucleotide sequence and genome organization of peach virus D, a putative new member of the genus Marafivirus. Arch. Virol. 2017, 162, 1769-1772. [CrossRef] [PubMed]

8. Marais, A.; Faure, C.; Couture, C.; Bergey, B.; Gentit, P.; Candresse, T. Characterization by deep sequencing of divergent Plum bark necrosis stem pitting-associated virus isolates and development of a broad-spectrum PBNSPaV detection assay. Phytopathology 2014, 104, 660-666. [CrossRef] [PubMed]

9. Candresse, T.; Faure, C.; Theil, S.; Marais, A. First report of Nectarine stem pitting-associated virus infecting Prunus mume in Japan. Plant Dis. 2017, 101, 393. [CrossRef]

10. Al Rwahnih, M.; Alabi, O.J.; Westrick, N.M.; Golin, D. Prunus geminivirus A: A novel Grablovirus infecting Prunus spp. Plant Dis. 2017. [CrossRef]

11. Jo, Y.; Lian, S.; Cho, J.K.; Chu, H.; Cho, W.K. First Report of Hop stunt viroid in Japanese Apricot (Prunus mume) in Korea. Plant Dis. 2017, 101, 1332. [CrossRef]

12. Massart, S.; Jijakli, M.M.; Kummert, J. Apple stem grooving virus. In Virus and Virus-Like Diseases of Pome and Stone Fruits; Hadidi, A., Barba, M., Candresse, T., Jelkmann, W., Eds.; American Phytopathological Society Press: St. Paul, MN, USA, 2011; pp. 29-33.

13. Nemchinov, L.G.; Gentit, G.; Zemcic, E.; Candresse, T.; Hadidi, A. Apricot latent virus. In Virus and Virus-Like Diseases of Pome and Stone Fruits; Hadidi, A., Barba, M., Candresse, T., Jelkmann, W., Eds.; American Phytopathological Society Press: St. Paul, MN, USA, 2011; pp. 97-101.

14. Gentit, P.; Foissac, X.; Svanella-Dumas, L.; Peypelut, M.; Candresse, T. Characterization of two different Apricot latent virus variants associated with peach asteroid spot and peach sooty ringspot diseases. Arch. Virol. 2001, 146, 1453-1464. [CrossRef] [PubMed]

15. Candresse, T.; Marais, A.; Faure, C.; Gentit, P. Association of Little cherry virus 1 with the Shirofugen stunt disease and characterization of the genome of a divergent LChV1 isolate. Phytopathology 2013, 103, 293-298. [CrossRef] [PubMed]

16. Youssef, F.; Marais, A.; Faure, C.; Barone, M.; Gentit, P.; Candresse, T. Characterization of Prunus-infecting Apricot latent virus-like Foveaviruses: Evolutionary and taxonomic implications. Virus Res. 2011, 155, 440-445. [CrossRef] [PubMed]

17. Foissac, X.; Svanella-Dumas, L.; Gentit, P.; Dulucq, M.J.; Marais, A.; Candresse, T. Polyvalent degenerate oligonucleotides reverse transcription-polymerase chain reaction: A polyvalent detection and characterization tool for Trichoviruses, Capilloviruses, and Foveaviruses. Phytopathology 2005, 95, 617-625. [CrossRef] [PubMed]

18. Thompson, J.D.; Higgins, D.G.; Gibson, T.J. CLUSTALW: Improving the sensitivity of progressive multiple sequence alignment through sequence weighting, position-specific gap, penalties and weight matrix choice. Nucleic Acids Res. 1994, 22, 4673-4680. [CrossRef] [PubMed]

19. Tamura, K.; Stecher, G.; Peterson, D.; Filipski, A.; Kumar, S. MEGA6: Molecular Evolutionary Genetics Analysis version 6.0. Mol. Biol. Evol. 2013, 3, 2725-2729. [CrossRef] [PubMed]

20. Petrzik, K.; Pribylova, J.; Koloniuk, I.; Spak, J. Molecular characterization of a novel capillovirus from red currant. Arch. Virol. 2016, 161, 1083-1086. [CrossRef] [PubMed]

21. Adams, M.J.; Candresse, T.; Hammond, J.; Kreuze, J.F.; Martelli, G.P.; Namba, S.; Pearson, M.N.; Ryu, K.H.; Saldarelli, P.; Yoshikawa, N. Family Betaflexiviridae. In Virus Taxonomy-Ninth Report on the International Committee on Taxonomy of Viruses; King, A.M.Q., Adams, M.J., Carstens, E.B., Lefkowitz, E.J., Eds.; Elsevier Academic Press: Cambridge, MA, USA, 2012; pp. 920-941. 
22. Yoshikawa, N.; Imaizumi, M.; Takahashi, T.; Inouye, N. Striking similarities between the nucleotide sequence and genome organization of citrus tatter leaf and apple stem grooving capilloviruses. J. Gen. Virol. 1993, 74, 2743-2747. [CrossRef] [PubMed]

23. Shim, H.; Min, Y.; Hong, S.; Kwon, M.; Kim, D.; Kim, H.; Choi, Y.; Lee, S.; Yang, J. Nucleotide sequences of a Korean isolate of Apple stem grooving virus associated with black necrotic leaf spot disease on pear (Pyrus pyrifolia). Mol. Cells 2004, 18, 192-199. [PubMed]

24. Marais, A.; Candresse, T.; Svanella-Dumas, L.; Jelkmann, W. Cherry virus A. In Virus and Virus-Like Diseases of Pome and Stone Fruits; Hadidi, A., Barba, M., Candresse, T., Jelkmann, W., Eds.; APS Press: St. Paul, MN, USA, 2011; pp. 147-150.

25. Desvignes, J.C.; Boye, R.; Cornaggia, D.; Grasseau, N. Apple stem grooving virus. In Virus Diseases of Fruit Trees; Hassan, M., Myrta, A., Polák, J., Eds.; Centre Technique Interprofessionnel des Fruits et Légumes (CTIFL): Paris, France, 1999; pp. 155-156.

2018 by the authors. Licensee MDPI, Basel, Switzerland. This article is an open access article distributed under the terms and conditions of the Creative Commons Attribution (CC BY) license (http:/ / creativecommons.org/licenses/by/4.0/). 